If these amendments become law, of which at present there seems every prospect, the outlook is indeed grave. No limit can at present be set to the area which will be affected by the exploitation of mineral rights. Difficulties have arisen when compensation has been given for expropriated native rights in land in the form of substituted areas. The consequences of a money payment in its effect on tribal feeling and on tribal character will be serious. To divorce the native from his land, which to him is sacrosanct, is to incur the risk of causing unrest and creating a native problem no less, and possibly even more, serious than the problem of the detribalised native in South Africa. Matters should not be allowed to rest here.

\section{Imported Books in Australia}

Early this year (Nature, Feb. 20 and April 2), we commented on the unfortunate effect on scientific and educational progress in Australia likely to be produced by the primage duty and sales tax on books, periodicals and magazines. We welcome, therefore, the announcement made on November 10 in the House of Representatives by Mr. Lyons, the Prime Minister, that these taxes are to be abolished (Sydney Morning Herald). They were introduced, with much other taxation, as part of the emergency measures necessary to meet the financial situation in Australia. A duty of 10 per cent on imported books and a sales tax of 6 per cent, together with the depreciation of Australian money, was clearly a heavy burden for scientific workers and others anxious to keep abreast of the times to bear, and an influential deputation waited upon Mr. Lyons asking for the remission of these taxes. As we pointed out at the time, and also when the Import Duties Bill proposing a duty of 10 per cent on goods imported into Great Britain was before the House of Commons, the revenue to be expected from the taxation of scientific literature in particular is negligible; such duties increase the cost of research and thereby hamper progress. Now that the budgetary position in Australia has improved to the extent that reduction of taxation can be considered, we are glad to find that the abolition of the primage duty and sales tax on literature is in the first group of measures brought forward.

\section{Jubilee of the Basic Steel Process in France}

THE basic steel process was introduced into France in 1882, and to mark the fiftieth anniversary, a special meeting of the Société des Ingénieurs Civils de France was held in Paris on December 5, the President of the Republic, M. A. Lebrun, honouring the proceedings by presiding. Four addresses were given dealing with the history of the basic process, and another on the iron ore district of Lorraine. The Iron and Steel Institute was represented by the president, Sir Charles Wright, Mr. F. W. Harbord and Mr. G. C. Lloyd, who prior to the official proceedings were received in private audience at the Palais de L'Elysede by the President of the Republic. The basic steel process which made possible the utilisation of huge deposits of hitherto practically useless phosphoric ores, was the invention of Sidney Gilchrist Thomas $(1850-85)$ who worked at the subject while a clerk in a London police court. His first paper, written in collaboration with his cousin Percy Carlyle Gilchrist, "On the Elimination of Phosphorus in the Bessemer Converter" was to have been read at the Paris meeting of the Iron and Steel Institute in 1879 , but for want of time had to be omitted. Thomas, however, was brought into contact with E. W. Richards and then J. E. Stead, and a successful demonstration of the process was made on April 4, 1879, at the Cleveland Steel Works. Thomas unfortunately did not live long to enjoy his triumph, for after travelling in search of health, he died in Paris on February 1, 1885, and was buried in the Passy cemetery.

\section{Education and International Organisation}

Tar report of the Sixth Committee to the Assembly of the League of Nations on the work of the International Organisation for Intellectual Co-operation stresses the importance of the educationsl questions with which the International Committee has been concerned, particularly those concerned with instruction in the aims and work of the League. Inquiries on the training of primary and secondary school teachers and the efforts made to facilitate the revision of school textbooks are of the greatest importance for the development of a spirit of world citizenship and the replacement of the partisan and nationalistic teaching of history and geography by a presentation alike scientific in method and world. wide in sympathy. Links are being created between university organisations and national educational information centres, and the report stresses the advantages obtainable from a new orientation of broadcasting and the cinema, with the assistance and guidance of teachers.

EFForts in the field of continuation courses and adult education have continued, while the research work on international relations, of which the report on the intervention of the State in economic life at the Milan Conference last May was the outcome, is being pursued, and the results of inquiries carried out in an objective and disinterested spirit will be discussed at a further meeting of men of science. Stress was laid on the work to be done by the Press in raising the intellectual level of mankind and a resolution adopted by the Assembly requests the organisation to study the methods by which the Press might contribute to a better understanding between the peoples of the world by perfecting their knowledge. Reference is also made in the report to the successful co-operation established with the Chinese Government to facilitate the extensive schemes of educational re-organisation drawn up by the latter, and the report of the mission of educational experts sent to China, like the report presented by a representative of the Educational Cinematographic Institute, embodies ideas regarding the establishment of a system of public education which should be of value to all governments.

No. 3296 , VoL. 130] 